\title{
Outreach and Financial Sustainability of Microfinance Banks in Southwest Nigeria
}

\author{
Musa A. Olasupo ${ }^{1}$, Carolyn A. Afolami ${ }^{2} \&$ Adebayo M. Shittu ${ }^{2}$ \\ ${ }^{1}$ Development Finance Office, Central Bank of Nigeria, Abeokuta, Ogun State, Nigeria \\ ${ }^{2}$ Department of Agricultural Economics and Farm Management, Federal University of Agriculture, Abeokuta, \\ Ogun State, Nigeria \\ Correspondence: Musa A. Olasupo, Development Finance Office, Central Bank of Nigeria, Abeokuta, Ogun State, \\ Nigeria. Tel: 234-803-359-7423. E-mail: maolasupo@cbn.gov.ng
}

Received: November 13, 2013

Accepted: November 28, 2013

Online Published: January 23, 2014

doi:10.5539/ijef.v6n2p25

URL: http://dx.doi.org/10.5539/ijef.v6n2p25

\begin{abstract}
Microfinance Banks (MFBs) in Nigeria are still a far cry from meeting their potentials as instrument of genuine economic development through the empowerment of the economic active poor whose core economic activities are located along the agricultural value chains. We examined the outreach and financial sustainability of MFBs to ascertain how well they have contributed to the financial intermediation process and also provide insight into their readiness as catalyst for the financial inclusion strategy. We measured outreach through technical efficiency and financial sustainability through economic efficiency using Data Envelopment Analysis for the activities of 86 MFBs in South-West, Nigeria. We observed a mean annual technical efficiency score of 0.464 and $30.23 \%$ of the sampled MFBs had technical efficiency score estimates of between 0.61 and 1.0. The mean economic efficiency score was 0.055 with a maximum of 2 MFBs on the economic efficiency score range of 0.81 and 1.0 over the study period. The mean economic efficiency of MFBs located in commercial areas was 0.0712 greater than the mean economic efficiency of their counterparts in the agrarian areas. Overall, the study depicted the Nigerian Microfinance sub-sector to be at its infancy (stage) and hence needs to be nurtured to achieve its potentials.
\end{abstract}

Keywords: microfinance banks, outreach, financial sustainability, efficiency

\section{Introduction}

A healthy financial system has long been recognized as a catalyst for economic growth and development. Hence, with available evidences (e.g., Honohan \& King, 2009) showing that most of the economically active people in Africa and other developing countries are not being reached by the formal financial system, enhancing effective "micro" financial services (microfinance) delivery to the huge number of poor people in the developing countries is considered important in the pursuits of some of the Millennium Development Goals (MDGs) and crucial for robust economic growth and development (CBN, 2005; Dunford, 2006; Montgomery \& Weiss, 2011). It is believed that by extending "small", "user friendly" and "collateral free" loans as well as deposit, insurance and other financial services to the poor, their latent entrepreneurial capacity can be enhanced, and the people enabled to undertake more rewarding economic activities and investments that can lead to sustainable increases in their income and significant poverty reduction (CBN, 2005; Hermes \& Lensink, 2011).

Evidences from many studies across the developing countries (Pitt \& Khandker, 1998; Khandker, 2005; Dunford, 2006; Chemin, 2008; Odell, 2010; Noreen et al., 2011 among others) affirm that microfinance do help to significantly reduce household poverty, most especially when channelled through women. Some (e.g., Noreen et al., 2011) also identified positive impacts of microfinance as including increased consumption expenditure, consumption smoothening, reduction in vulnerability, increased level of the poor's children education, and women empowerment, among others. However, a number of recent studies (e.g., Copestake et al., 2005; Roodman \& Morduch, 2009; Banerjee et al., 2009; Duvendack \& Palmer, 2012) drew attention to the need for caution in accepting these celebrated evidences as true on the ground that many of the reported impacts were incorrect due to failure to correct for selectivity bias, or that the evidences are mixed (i.e. not always true), and/or could not be strictly ascribed to microfinance per se given that many of the recipients had access to multiple sources of credit In a systematic review of evidences on microfinance impacts in sub-Saharan Africa, van Rooyen et al. (2012) 
concluded that "microfinance in sub-Saharan Africa-while it has modest but not uniform positive impacts - is not always a golden bullet, but indeed can cause harm", which, in some cases, include increased poverty, reduced levels of children's education and disempowerment of women. This, they noted, calls to question the often hyped microfinance role in the pursuit of MDGs. A close examination of evidences in literature suggests, however, that such negative microfinance outcomes may be linked to poor conceptualisation, packaging and delivery of microfinance schemes. There have been questions as to whether or not the poorest of the poor are really being reached as to justify the use of funds that could otherwise be applied in pursuit of other poverty alleviation programmes in funding/supporting microfinance schemes (Scully, 2004; Simanowitz, 2002). Questions are also being asked as to whether or not activities of microfinance institutions are sustainable in the long term, given the possible trade-off between the emphasis on poverty reduction as against that of financial sustainability of the MFIs as businesses (Hermes \& Lensink, 2011).

This study is an attempt to examine the question of financial sustainability of MFIs, using cases of Microfinance Banks (MFBs) in Southwest Nigeria as an example. The need to critically examine issues relating to operational efficiency and financial sustainability of MFBs in Nigeria is particularly justified given that a recent target examination of the 820 MFBs licensed between 2005 and date by the Central Bank of Nigeria revealed that many of the MFBs were 'Terminally Distressed' and 'Technically Insolvent' and/or had closed shop for at least six months. Hence, the withdrawal of operating licenses of 224 MFBs in Nigeria in September, 2010.

\section{Background Information and Literature Review}

\subsection{Microfinance Institutions and Operating Philosophy}

Microfinance institutions (MFIs) refer to a broad range of diverse institutions that offer financial services to low-income clients, which include non-governmental organizations (NGOs), non-bank financial institutions, cooperatives, rural banks, savings and postal financial institutions, microfinance banks (MFBs) and an increasing number of deposit money banks (DMBs). The nature of these institutions departs from the traditional financial institutions (Deposit Money Banks) as they are smaller in size, limited in their services and often provide small collateral-free group loans. The basic operational objectives of MFIs revolve around two approaches or paradigms namely the "institutionist" and the "welfarist paradigms". The "institutionist paradigm", postulates that MFIs should generate enough revenue to meet their operating and financing costs and the "welfarist paradigm", which focuses on poverty alleviation and depth of outreach along with achieving financial sustainability. Brau and Woller, (2004) concluded that an efficient MFI management should promote these two objectives.

The main objectives of microfinance institutions are viewed differently by authors. Christen et al. (1995) argued that increasing access to reach the poorest of the poor (depth of outreach) and sustainability are compatible objectives, which they believe can be jointly pursued. Hulme and Mosley (1996), Lapenu and Zeller (2002), with others argued that a trade-off may become evident as the MFI strive to achieve a balance between augmenting outreach to the poorest and attaining financial sustainability. The financial sustainability of the financial institutions and outreach to the poor are two of the three policy objectives of the contemporary developments in the field of microfinance. The third policy object is Welfare impact and it relates to the development of the financial system and precisely in relation to economic growth, poverty alleviation and food insecurity. The crucial triangle of microfinance reflects the three policy objectives of Micro Finance (MF) of outreach, financial sustainability and impact. Zeller and Mayer (2002) concluded that some of these objectives contribute more impact and at the same time inadequate outreach, while the other objectives may produce limited impacts but are very much financially sustainable.

Financial sustainability is determined by the depth of resources utilization efficiency by MFIs and how they turn those resources into services. Knowledge of the determinants of efficiency would help to increase our understanding of what determines financial stability and also of the potential of microfinancing in making a significant and long-term contribution to poverty reduction. It is argued that MFIs that are financially sustainable with high outreach have a greater livespan and also have a positive impact on small and medium enterprise (SME) development because they guarantee sustainable access to credit by the poor (Rhyne \& Otero, 1992).

\subsection{Historical Perspectives to Microfinance Banking in Nigeria}

The earliest evidence of financial institution in Africa was the esusu, it dated as far back as the $16^{\text {th }}$ century and represented a form of rotating savings and credit association (ROSCA) among the Yorubas of South-Western Nigeria. These informal financial institutions are quite popular in every part of the Country with each ethnic group having its own institutions and proper names like adashi among the Hausas and Osusu or Isusu among the Igbos. In 1940s, the colonial officers in Eastern Nigeria recommended the transformation of Isusu into formal financial cooperatives and also the sustenance of Isusu practices within modern cooperatives (i.e., those registered under the 
cooperative law (Siebel, 2004).

Government has over the years evolved a variety of economic development programmes and policies aimed at delivering affordable and sustainable credit to the active poor in the rural areas due to the perceived credit imbalance and financial distortion between the rural and urban areas. Some of these interventions include Rural Banking Scheme, People's Bank, Operation Feed the Nation (OFN), Green Revolution, Nigerian Bank of Commerce and Industry (NBCI), Nigerian Agricultural and Cooperative Bank (NACB) among others.

The CBN having noticed the low level of rural savings mobilization, inadequate use of banking services and lack of credit for the rural populace instituted the Rural Banking Scheme (RBS) in 1977 in an attempt to kick start the SME revolution. The underlying assumptions were increasing the proximity of banks to the rural populace will enhance rural savings mobilization, ultimately increase the flow of funds to the rural populace, provide credit support for agriculture and agro-allied activities and curb rural-urban migration (CBN, 2009). The scheme operated till 1989 with little impact as most commercial banks did not consider the viability of rural branches as profit centers while the few that opened rural branches closed them down after few years of operation.

The community banking concept was initiated with the 1990 budget speech of the President of the Federal Republic of Nigeria but promulgated into law in 1992. The law defined community banks as a financial institution established to cater for savings and credit needs of small scale producers throughout the country. The community banking concept experienced minimal success in terms of outreach and sustainability and suffered grossly from weak institutional capacity, weak capital base etc. Also the need for increased savings opportunity, economic empowerment of the poor, increased employment generation, poverty reduction etc were potentials inherent in the sub-sector that were not met (CBN, 2005).

The Banking and Other Financial Institutions Act of June 1999 gave legal backing to the CBN to assume the regulation and supervision of the Community Banks and new guidelines stating the licensing requirements for their operations was issued. The CBN embarked on a licensing exercise for the Community Banks (CBs) with emphasis on all those operating with the provisional licenses issued by the defunct regulator, the National Board for Community Banks (NBCB). By 20002, only 282 CBs of the 1,013 CBs transferred to the CBN by the NBCB qualified for the final license (CBN, 2009).

The Microfinance Policy, Regulatory and Supervisory Framework for Nigeria was launched on the $15^{\text {th }}$ December, 2005 and it provided a new frontier for the operations of banks in the sub-sector. The framework among other guidelines encouraged the conversion of the existing $759 \mathrm{CBs}$ to Microfinance Banks (MFBs) over a 2 years grace period, with a deadline of December, 2009 for compliance. CBs were required to convert into any of the two MFBs categories (Unit MFB or State MFB), while Non-governmental organizations engaged in microfinancing and met the stipulated licensing requirements were encouraged to transform to the relevant categories of the MFB. As at December, 2007 after the grace period, 607 CBs had successfully converted to MFBs while 223 new MFB licenses had been issued bringing the total number of MFBs to 830 as at $31^{\text {st }}$ December, 2008 (CBN, 2009).

However, in September, 2010, the CBN revoked the operating licenses of 224 MFBs after the Target Examination conducted on 820 MFBs, which found them to be 'Terminally Distressed' and 'Technically Insolvent' and/or had closed shop for at least six months.

\subsection{Framework for Assessing Efficiency and Sustainability Microfinance Institutions}

Farell (1957) defined technical efficiency as the ability of a producer to produce maximum output from a given set of inputs. Measurement of technical efficiency is vital as: it is a success indicator of performance measure to evaluate production units; measurement of causes of inefficiency highlights the sources of inefficiency and how best to eliminate them; and the identification of sources of inefficiency is essential for institutions that care about improved performance.

Ben Amor and Muller (2010) reported that original frontier function model introduced by Farrell (1957) used the efficient unit isoquant to measure economic efficiency and to decompose it into technical efficiency and allocative efficiency. In this model, Technical Efficiency (TE) is defined as the firm's ability to produce maximum output given a set of inputs and technology. Stated differently, technical inefficiency measures the failure of attaining the highest possible level of output given input and technology. Conversely, Allocative (or price) Efficiency (AE) reflects the firm's success in choosing the optimal input proportions, i.e. where the ratio of marginal products for each pair of inputs is equal to the ratio of their market prices. In Farrell's framework, economic efficiency is a measure of overall performance and is equal to the product of $\mathrm{TE}$ and $\mathrm{AE}$.

Given the importance of frontier estimation and the growing enthusiasm in technical efficiency analysis, several models of frontiers have been developed. The idea of frontier estimation is to replace the classical approach of 
efficiency measurement, which was structured on the ratio of output to a particular input (partial productivity measure). Misgivings about with the shortcomings of the classical approach led economists to develop advanced econometric and linear programming methods (the frontier methods). These two methods are both based on the concept of a frontier. The efficient producing units operate on the production frontier, while inefficient producing units operate below the production frontier and the level of inefficiency is measured by the level of deviation from the frontier.

To analyze the relative technical efficiency of any sort of financial institution, it is necessary to define the approach that will be adopted in order to measure the flow of services provided by the institution. One of two main approaches is usually selected, however this study considered both approaches.

1) Production Approach: This approach considers financial institutions as firms that produce services for their clients or as a factory producing services to the poor households. In this approach, output is best measured by the number and type of transactions (or by the number of participants) processed over a given period of time. Nevertheless, as information on the flow of transactions is not usually available, data on the stock of the number of deposit or loan accounts or the number of insurance policies outstanding as of a given date are used as a substitute proxy (Fried, Knox Lovell, \& Schmidt, 2008). Berg, FØrsund and Jansen (1991), have used different production outputs keeping the input (such as labor, fixed assets, capital) remaining the same. Sherman and Gold (1985), for example, used the number of transaction as the output while Ferrier and Lovell (1990) used the total number of accounts and account size as the output.

2) Intermediation Approach: This approach considers financial institutions primarily as firms that intermediate funds between savers (depositors) and investors (borrowers). The purpose of intermediation is the transfer of purchasing power from surplus to deficit units, which improves the allocation of resources in the economy (Gonzalez-Vega, 1986). It considers the transformation of deposits and other loanable funds into credit. Berger and Humphrey (1992) argued that this approach failed to consider the cost of financial transactions and savings deposits.

Data envelopment analysis is a Linear Programming Model that provides a means of calculating apparent efficiency levels within a group of organizations. The efficiency of an organization is calculated relative to the group's observed best practice.

The use of DEA in this study is appealing because of the following:

1) DEA can easily accommodate both multiple inputs and outputs unlike the Stochastic Frontier production function.

2) DEA does not require the imposition of a specific functional form on the model. This allows the technological frontier to be constructed without imposing a parametric functional form on technology or deviations from it (inefficiencies).

3) It permits the construction of a surface over the data, which allows comparison of one production method (or best producer) with others, in terms of a performance index.

\subsection{Empirical Evidences on Efficiency and Sustainability Microfinance Institutions}

Studies on the efficiency of MFIs are becoming germane as researchers strive to balance the numerous claims attributed to the potentials of microfinance as a poverty reduction tool. However, not much has been done on the efficiency of MFIs using either parametric or non-parametric approaches. Farrington (2000) identified a number of accounting variables to reflect the efficiency of the microfinance institutions. The variables identified included administrative expense ratio, number of loans per loan officer and loan officers to total staff. Portfolio size, loan size, lending methodology, source of funds and salary structure were identified as efficiency drivers. Lafourcade et al. (2005) used cost per borrower and cost per saver as measure of efficiency. They observed that African MFIs incur highest costs per borrower but have the lowest costs per saver. They also mentioned that regulated MFIs maintain higher efficiency through low costs per borrower and per saver. In contrast, African cooperative-MFIs were the least efficient with the highest cost per borrower. Nevertheless, cooperative-MFIs have the lowest cost per saver but unregulated MFIs have the highest. None of these two studies used any parametric or non-parametric approach to evaluate the efficiency of MFIs.

Until recently, the issue of efficiency has been less commonly examined with parametric models. Hassan and Tufte (2001) used a parametric approach (stochastic frontier analysis or SFA) and observed that Grameen Bank's branches staffed by female employees operated more efficiently than their counterparts staffed by male employees. Desrochers and Lamberte (2003) also used parametric approaches to study the efficiency of cooperative rural banks in the Philippines and found that cooperative rural bank with good governance were more efficient than their counterparts laced by bad governance. 
Martinez-Gonzalez (2008) studied the relative technical efficiency of a sample of microfinance institutions (MFIs) in Mexico using DEA and identified the determinants of the differences in efficiency using Tobit regression. Results of the intermediation and production approaches suggested that most MFIs were more efficient pursuing sustainability rather than outreach or have not met either objective successfully, but the trend reverted in 2007. The study also revealed that average size of loan, proportion of assets used as performing portfolio, percentage of FINAFIM funds, scale of operations, ratio of payroll to expenses, age, structure of the board, and for-profit status of the MFI were the significant determinants of the MFIs' efficiency.

Haq, Skully and Pathan (2009) examined the cost efficiency of 39 microfinance institutions across Africa, Asia and the Latin America using non-parametric data envelopment analysis. Their findings showed that non-governmental microfinance institutions particularly; under production approach, were the most efficient and this result is consistent with their fulfillment of dual objectives: alleviating poverty and simultaneously achieving financial sustainability. However, bank microfinance institutions also outperformed in the measure of efficiency under intermediation approach. This result reflects that banks are the financial intermediaries and have access to local capital market. It may be possible that bank microfinance institutions may outperform the non-governmental microfinance institutions in the long run.

\section{Data and Methods}

The choice of south-western Nigeria was informed by relevant statistics that depicted the zone as the most financial literate among the geo-political zones in the country. Enhancing Financial Innovation and Access (EFInA) in 2010 reported that the South-West zone had the highest percentage in terms of access to finance with $56 \%$ of the population having access to any of formal banked, formal non-bank and informal sources of finance while $44 \%$ of the population remains financially excluded. The survey also hinted that $55 \%$ of the twenty largest MFBs in Nigeria were in the South-West, and only 5\% was in the North Central Zone. In 2009, the CBN gave the geographical distribution of the 883 licensed MFBs in Nigeria as follows: North-West (6.8\%), North-Central (13.7\%), North-East (3.7\%), South-West (41.9\%), South-South (13.8\%), and South-East (20\%).

All the MFBs in Ogun, Ondo and Oyo States after the CBN's revocation exercise of 2010 were involved in this study. For this study, MFBs were restricted to Unit Microfinance Banks (i.e., MFBs with $\$ 20$ million capital requirement). This restriction was expected to create a fair platform to assess the operations of firms on a similar operational level. Operational information were sourced from the MFBs from 2006 to 2010.

\subsection{Data Envelopment Analysis}

This analysis was modeled after similar work by Martinez-Gonzalez (2008) in the estimation of the efficiency scores of MFIs under both the production and intermediation approaches. Technical efficiency (input oriented measures) only was estimated using the production approach as emphasis was on the bank as a productive unit and hence outreach as the MFBs' objective, while economic efficiency was measured using the intermediation approach. The study estimated efficiency scores for all years from 2006 to 2010. The input oriented measure was adopted under the premise of scarcity of resources and resource-use optimization as MFBs were expected to optimize the minimum resources at their disposal.

Suppose we have $\mathrm{n}$ productive units, each unit produces $\mathrm{u}$ outputs while consuming $\mathrm{v}$ inputs.

Input matrix $\mathrm{V}=\left\{\mathrm{v}_{\mathrm{ij},} \mathrm{i}=1,2, \ldots, \mathrm{m}, \mathrm{j}=1,2, \ldots, \mathrm{n}\right\}$

Output matrix $U=\left\{u_{i j}, i=1,2, \ldots, s, j=1,2, \ldots, n\right\}$

For the production approach,

$\mathrm{v}_{1}=$ MFB's cost per borrower ( $\left.\mathrm{N}\right)$;

$\mathrm{v}_{2}=$ MFB's cost per saver $(\AA)$

$\mathrm{v}_{3}=$ MFB's number of staff;

$\mathrm{u}_{1}=$ MFB's number of borrowers per staff member;

$\mathrm{u}_{2}=$ MFB's number of savers per staff member;

For the intermediation approach,

$\mathrm{v}_{1}=$ MFB's operating expenses ( $)$;

$\mathrm{v}_{2}=$ MFB's salaries and wages ( $)$;

$\mathrm{u}_{1}=$ MFB's gross loan portfolio ( $)$;

$\mathrm{u}_{2}=$ MFB's total savings. 
For each MFB, we would like to obtain a measure of the ratio of all outputs over all inputs, such as $u^{\prime} y_{i} / v^{\prime} x_{i}$

where $\mathrm{u}$ is a $\mathrm{Mx} 1$ vector of output weights and $\mathrm{v}$ is a $\mathrm{Kx} 1$ vector of input weights. To select optimal weights we specify the mathematical programming problem:

$\max _{\mathrm{u}, \mathrm{v}}\left(\mathrm{u}^{\prime} \mathrm{y}_{\mathrm{i}} / \mathrm{v}^{\prime} \mathrm{x}_{\mathrm{i}}\right)$,

$$
\text { st } \quad u^{\prime} y_{j} / v^{\prime} x_{j} \leq 1, j=1,2, \ldots, N ; u, v \geq 0 .
$$

This involves finding values for $u$ and $v$, such that the efficiency measures of the i-th MFB is maximized, subject to the constraint that all efficiency measures must be less than or equal to one. As earlier stated, a major problem with this particular ratio in that it has an infinite number of solutions, which can be avoided by imposing the constraint $\mathrm{v}^{\prime} \mathrm{x}_{\mathrm{i}}=1$, which provides:

$\max _{\mu, v}\left(\mu^{\prime} y_{i}\right)$,

$$
\text { st } \quad v^{\prime} x_{i}=1, \quad \mu^{\prime} y_{j}-v^{\prime} x_{j} \leq 0, j=1,2, \ldots, N ; \mu, v \geq 0 .
$$

where the notation from $u$ and $v$ to $\mu$ and $v$ reflects the transformation. This form is known as the multiplier form of the linear programming problem.

Using the duality in linear programming, one can derive an equivalent envelopment form of this problem:

$\operatorname{Min}_{\theta, \lambda} \theta$,

$$
\text { st } \quad-y_{i}+Y \lambda \geq 0, \theta x_{i}-X \lambda \geq 0, \lambda \geq 0 .
$$

where $\theta$ is a scalar and $\lambda$ is a $\mathrm{Nx} 1$ vector of constants.

\subsection{Tobit Analysis}

Inefficiency increases cost and ceteris paribus reduces profit. Identification of inefficient MFBs and the sources of inefficiency are crucial to promoting efficient utilization of resources and hence to enhancing profitability. The study examined the effect of the age of the MFBs, location (e.g agrarian or commercial area), operational strategy of MFB (only micro credit or micro credit and other services like insurance, consultancy, leasing and money transfer), average loan size, quality of management, etc, on the efficiency of MFBs in the study area. Since the DEA efficiency scores lies in the interval of 0 and 1 , the dependent variable is a "limited dependent variable" and hence the use of the Tobit model, which is a censored regression model, applicable in cases where the dependent variable is constrained. This study regressed DEA efficiency scores against relevant efficiency drivers modeled after previous works by Martinez-Gonzalez (2008), and Tripathy et al. (2009). A pooled data of all years (2006 to 2010) was used to assess the influence of the identified efficiency drivers on the efficiency of MFBs under the production and intermediation approaches. The use of efficiency scores will also adjust for differences resulting from sizes and scale of operation.

The Tobit model may be defined as:

$$
\begin{aligned}
& \mathrm{y}=\left\{\begin{array}{l}
y * ; 0 \leq y * \leq 1 \\
0 ; y *<0 \\
1 ; 1<y *
\end{array}\right. \\
& \mathrm{y}^{*}=\beta \mathrm{x}_{\mathrm{i}}+\varepsilon_{\mathrm{t}} \quad \varepsilon_{\mathrm{t}} \sim \text { i.e } \mathrm{N}\left(0, \sigma^{2}\right)
\end{aligned}
$$

where $y$ is the DEA VRS EE score.

$y^{*}$ is a latent (unobservable) variable.

$\beta$ is the vector of unknown parameters which determines the relationship between the independent variable and the latent variable.

$\mathrm{x}_{\mathrm{i}}$ is the vector of explanatory variables or efficiency drivers.

The socio-economic variables that will be included in the explanatory variables are:

1) Age of MFB: Microfinance is perceived as being labour intensive as it requires a lot of contact between the service provider and clients to build trust. Age was measured by number of years in operation since legal establishment and the a priori expectation of the sign of this variable is positive $(+)$.

2) Location: The locations of MFBs are classified as agrarian or commercial. Dummy variable was be used to represent the location of the MFB, assuming a value of 1 for MFBs located in an agrarian area and zero otherwise.

3) Operational Strategy: The depth of financial and other services provided by an MFB is an indicator of asset usage and hence profitability. Dummy variable was used to capture this effect with a value of 1 for MFBs that 
offers micro credit and other services and zero for MFBs that provide only micro credit.

4) Scale of Operations: Measured as mean gross loan portfolio under the intermediation approach and mean number of clients under the production approach.

5) Quality of Management Staff: Academic and professional experience of top management staff is expected to increase the Banks' efficiency. Educational qualification was used as a proxy for the quality of management staff and represented by an educational index calculated by the cumulative educational qualification of all management staff divided by the number of management staff. Educational qualification will be ranked as: primary education (1), secondary education (2), tertiary education (3) and professional qualification (4). These ranks will be multiplied by the number of management staff that attains any level as the highest educational qualification and divided by the total number of management staff for standardization.

6) External Sources of Funds: This is measured as loans, grants and other sources of wholesale funds outside shareholders' equity that are available for funding the operations of the MFB. External sources of funds provide better pedestal to reach more clients and provide more loanable funds and also could influence the MFBs' ability to provide cheaper services to its' clients and hence enhance its profitability and efficiency.

The Tobit model for the MFBs can be explicitly stated as:

$$
\begin{aligned}
& y^{*}=\alpha+\beta_{1} \text { Age }-\beta_{2} \text { Location }+\beta_{3} \text { Quality of Management }+\beta_{4} \text { Operational Strategy } \\
& +\beta_{5} \text { Average number of clients. (Production Approach) } \\
& y^{*}=\alpha+\beta_{1} \text { Age }+\beta_{2} \text { Location }+\beta_{3} \text { Quality of Management }+\beta_{4} \text { Operational Strategy } \\
& +\beta_{5} \text { Gross Loan Portfolio }+\beta_{6} \text { External sources of funds. (Intermediation Approach) }
\end{aligned}
$$

\section{Results and Discussion}

Only 86 out of the 118 administered questionnaires were returned in formats useful for our analysis. Over the period, the total number of active borrowers across the sampled MFBs stood at 64,321 clients in 2006 to 125,875 clients in 2010. The mean value of active borrowers ranged from 748 clients in 2006 to 1,464 clients in 2010 . The total number of women borrowers increased from 40,118 clients in 2006 to 79,801 clients in 2010. The mean active savers ranged from 1,821 in 2006 to 3, 272 in 2010. The average number of female savers represented $56.73 \%$ of the total average number of savers, which further corroborated the general saying that microfinance is more focused on women. The sampled MFBs continually improved on their outreach in terms of number of active clients with an annual growth of 16.67\%,21.99\%, 17.13\% and 10.57\% for years 2007, 2008, 2009 and 2010 respectively.

In general, the sampled MFBs mean total savings mobilized ranged between $\$ 42.70$ million to $\$ 54.88$ million, while women savings represented $63.19 \%$ and $57.14 \%$ of the total savings in 2006 and 2010 respectively. The mean quantum of loans sought by the MFBs' clients per bank ranged between (was) $\$ 37.60$ million in 2006 and reached $\$ 54.88$ million in 2010. Due to funds limitation, unrealistic loan demands and other factors, total loans disbursed represented $82.32 \%$ in $2006,82.36 \%$ in $2007,79.72 \%$ in $2008,83.30 \%$ in 2009 and $82.07 \%$ in 2010 . This trend left a credit gap of between $16.70 \%$ and $20.28 \%$ over the study period. The MFBs outstanding loans as a percentage of loans disbursed was $20.93 \%$ in 2006 and $19.41 \%$ in 2010 . The MFBs' loan portfolio was sub-divided into the agricultural sector (comprising of agricultural production activities and agro-processing related activities), commerce and other sectors. The total annual loans disbursed to agricultural related activities grew marginally by $0.93 \%$ in 2007 , but made significant leaps by recording growth figures of $19.95 \%, 21.39 \%$ and $5.0 \%$ in 2008,2009 and 2010 respectively. 
Table 1. Descriptive statistics of variables employed in the efficiency models of MFBs (2006-2010)

\begin{tabular}{|c|c|c|c|c|c|}
\hline Concept & 2006 & 2007 & 2008 & 2009 & 2010 \\
\hline \multicolumn{6}{|c|}{ Borrowers per Staff } \\
\hline Mean & 62 & 71 & 72 & 77 & 83 \\
\hline Std. Error & 8 & 9 & 11 & 11 & 12 \\
\hline \multicolumn{6}{|c|}{ Savers per Staff } \\
\hline Mean & 135 & 138 & 140 & 147 & 156 \\
\hline Std. Error & 22 & 21 & 24 & 25 & 25 \\
\hline \multicolumn{6}{|c|}{ Cost per Borrower (N'000) } \\
\hline Mean & 15.82 & 15.75 & 20.44 & 28.88 & 18.46 \\
\hline Std. Error & 2.52 & 2.62 & 5.43 & 12.18 & 3.91 \\
\hline \multicolumn{6}{|c|}{ Cost per Saver (N’000) } \\
\hline Mean & 8.53 & 9.05 & 9.39 & 8.54 & 8.16 \\
\hline Std. Error & 1.25 & 1.57 & 1.63 & 1.19 & 1.22 \\
\hline \multicolumn{6}{|c|}{ Number of Staff } \\
\hline Mean & 12 & 13 & 16 & 17 & 17 \\
\hline Std. Error & 0 & 1 & 1 & 1 & 1 \\
\hline \multicolumn{6}{|c|}{ Gross Loan Portfolio (N'm) } \\
\hline Mean & 37.60 & 39.28 & 48.20 & 59.99 & 67.45 \\
\hline Std. Error & 5.05 & 4.02 & 4.98 & 7.17 & 7.47 \\
\hline \multicolumn{6}{|c|}{ Total Savings (N’000) } \\
\hline Mean & 42.70 & 39.28 & 44.36 & 50.23 & 54.88 \\
\hline Std. Error & 7.14 & 5.24 & 4.68 & 5.45 & 5.68 \\
\hline \multicolumn{6}{|c|}{ Operating Expenses (N'm) } \\
\hline Mean & 6.14 & 6.69 & 9.55 & 11.81 & 12.34 \\
\hline Std. Error & 7.60 & 8.23 & 1.58 & 2.05 & 2.33 \\
\hline \multicolumn{6}{|c|}{ Salaries and Wages (N'm) } \\
\hline Mean & 4.64 & 4.71 & 5.93 & 6.90 & 7.59 \\
\hline Std. Error & 0.55 & 0.48 & 0.59 & 0.78 & 0.90 \\
\hline
\end{tabular}

Source: Field survey (2013).

\subsection{Technical Efficiency under Production Approach: Input Oriented Measure}

The result showed inconsistencies in the growth pattern of the MFBs over the study period. The mean technical efficiency score of the sampled MFBs (as shown in Figure 1) grew from 0.467 in 2006 to 0.525 in 2007. The efficiency score dropped to 0.408 in 2008; climbed to 0.477 in 2009 and further declined to 0.445 in 2010 . The input oriented estimates further revealed that only $20.93 \%$ of the sampled MFBs were on the efficiency frontier in 2006 , the percentages ranged from $26.74 \%$ in 2007 , slumped to $18.61 \%$ in 2008 , grew to $24.42 \%$ in 2009 and declined marginally to $23.26 \%$ in 2010 . Only $8.14 \%$ of the sampled MFBs had a technical efficiency score of between 0.71 and 0.99 . This percentage dropped to $4.65 \%$ in 2008 and $1.16 \%$ in 2010 . This sequence showed that more MFBs were becoming more technically inefficient over time. (and it was further corroborated by the increase reported in the percentage of MFBs rated within the technical efficiency range of 0.01 to 0.50 ). The VRS estimates showed that the MFBs were operating at different levels. The decreasing returns to scale (drs) stage had 4 MFBs in 2006, the value rose to $10 \mathrm{MFBs}$ in 2008 and fell to $7 \mathrm{MFBs}$ in 2010. Under the constant returns to scale category, the study reported 11 MFBs in 2006, fell to 6 MFBs in 2008 and rose to 15 MFBs in 2009 and later had 12 MFBs in 2010. The study also revealed that 71 MFBs were operating at increasing returns to scale in 2006; the value fell to 70 MFBs in 2008 and later to 67 MFBs in 2010.

\subsection{Economic Efficiency Estimates under the Intermediation Approach}

The three (3) efficiency scores (Figure 2) followed a similar pattern as the MFBs experienced annual increase in their mean technical, allocative and economic efficiency scores except in 2008 where the technical efficiency value dropped and in 2009 when the allocative and economic efficiency values declined. The annual mean technical efficiency score stood at 0.114 in 2006 and settled at 0.256 in 2010. The annual mean allocative efficiency score was 0.193 in 2006 and recovered to 0.330 in 2010. The annual mean economic efficiency score followed a similar pattern as the annual mean allocative efficiency score with a value of 0.024 in 2006 and rose to 0.085 in 2010. 
The study revealed that the MFBs were more allocatively efficient than being technically efficient. This might be due to their willingness to attract the best manpower by providing a competitive wage structure and also streamlining their operating expenses to achieve financial stability but hindered in terms of outreach and ability to provide loanable funds due to the level of funds available for their operations.

Also, extracts from the efficiency scores of the intermediation approach revealed the trend in the number of MFBs that were on the efficient frontier technically, allocatively and economically. In the period under survey, we observed a maximum of 3 MFBs on the economic efficiency frontier as reported in 2008. The other years had 1 or 2 MFBs on the frontier while other MFBs were economically inefficient. Also, the results showed that the MFBs fared better technically and allocatively in the later years of the study than in the earlier years. The study revealed that $83.72 \%$ to $96.51 \%$ of the sampled MFBs had a technical efficiency score range of between 0 and 0.50 , while the $59.30 \%$ to $82.56 \%$ recorded allocative efficiency scores of between 0 and 0.50 , and $94.19 \%$ to $98.84 \%$ had economic efficiency score of the same range. This depicts that most of the sampled MFBs are further away from the efficiency frontiers than those closer to the frontier (Table 2).

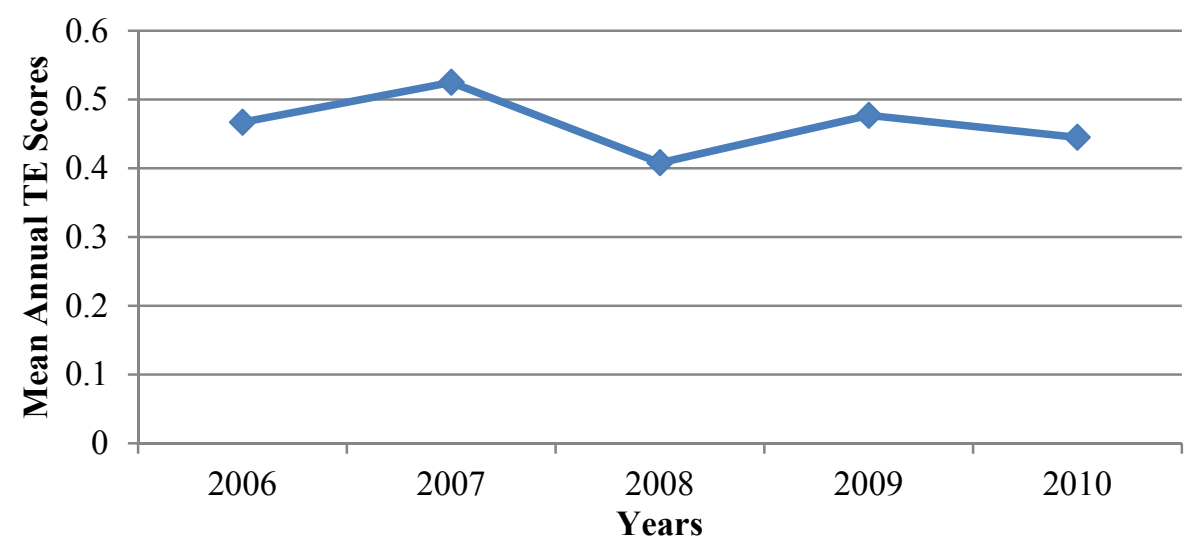

Figure 1. Trend in the mean technical efficiency index of MFBs in Southwest Nigeria

Table 2. Summary of the DEA technical efficiency result: input oriented measures

\begin{tabular}{llllll}
\hline Concept & 2006 & 2007 & 2008 & 2009 & 2010 \\
\hline Mean VRS TE Score & 0.467 & 0.525 & 0.408 & 0.477 & 0.445 \\
VRS Technical Efficiency & Score (range): & & & & \\
1 & 18 & 23 & 16 & 21 & 20 \\
$0.71-0.99$ & 7 & 5 & 4 & 0 & 1 \\
$0.51-0.70$ & 11 & 6 & 1 & 9 & 1 \\
$0.0-0.50$ & 50 & 52 & 65 & 56 & 64 \\
Scale of Operation: & & & & & \\
Drs & 4 & 8 & 10 & 9 & 7 \\
Crs & 11 & 11 & 6 & 15 & 12 \\
Irs & 71 & 67 & 70 & 62 & 67 \\
\hline
\end{tabular}

Source: Field survey (2013). 


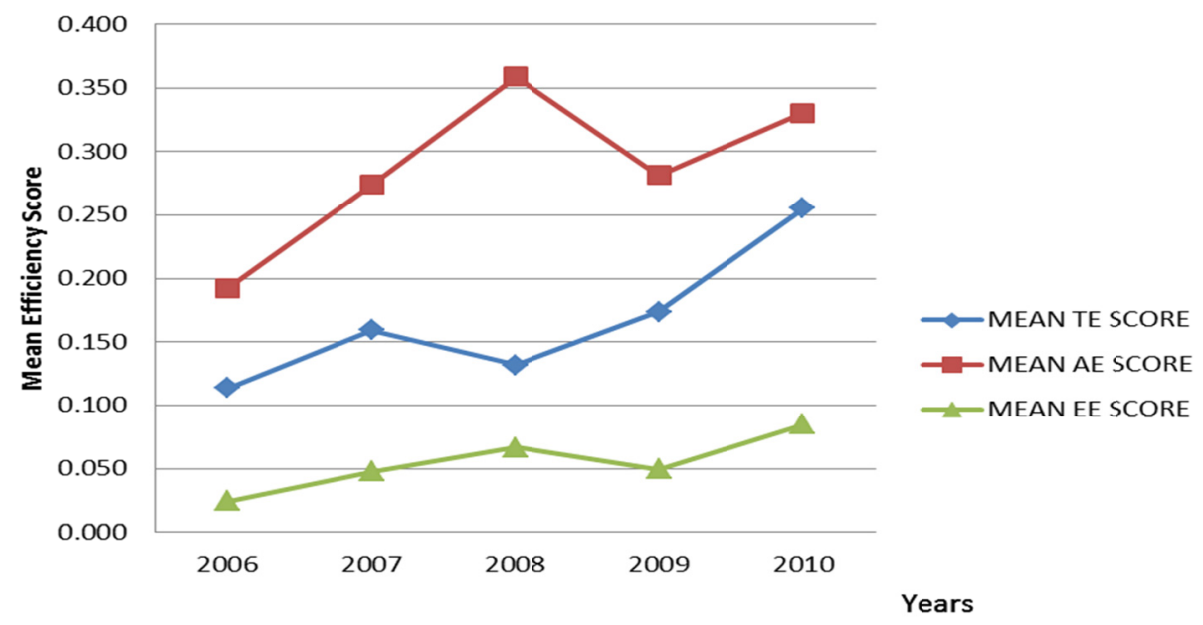

Figure 2. Trend in mean efficiency indexes of MFBs in South-West Nigeria under the intermediation approach

Table 3. Summary presentation of the DEA economic efficiency result

\begin{tabular}{llllll}
\hline Concept & 2006 & 2007 & 2008 & 2009 & 2010 \\
\hline Mean TE Score & 0.114 & 0.159 & 0.132 & 0.174 & 0.256 \\
Mean AE Score & 0.193 & 0.274 & 0.359 & 0.282 & 0.330 \\
Mean EE Score & 0.024 & 0.048 & 0.066 & 0.050 & 0.085 \\
Technical Efficiency Score (range) & & & & & \\
1 & 2 & 4 & 3 & 4 & 5 \\
$0.71-0.99$ & 0 & 2 & 1 & 2 & 4 \\
$0.51-0.70$ & 1 & 1 & 0 & 1 & 5 \\
$0.0-0.50$ & 83 & 79 & 83 & 79 & 72 \\
Allocative Efficiency Score (range) & & & & \\
1 & 11 & 17 & 17 & 18 & 17 \\
$0.71-0.99$ & 4 & 1 & 11 & 1 & 8 \\
$0.51-0.70$ & 0 & 2 & 1 & 1 & 0 \\
$0.0-0.50$ & 71 & 66 & 57 & 66 & 51 \\
Economic Efficiency Score (range) & 1 & & & & \\
1 & 0 & 2 & 3 & 2 & 1 \\
$0.71-0.99$ & 0 & 0 & 0 & 0 & 3 \\
$0.51-0.70$ & 85 & 84 & 0 & 0 & 84 \\
$0.0-0.50$ & & & & & \\
\hline
\end{tabular}

Source: Field survey (2013).

\subsection{Tobit Analysis}

Tables 4 and 5 showed the results of the Tobit regression for the production and intermediation approaches respectively. The result in Table 4 showed average number of clients and location of MFB as the determinants of technical efficiency of MFBs under the production approach at $1 \%$ and $10 \%$ levels of significance respectively. Average number of clients connotes the MFBs' outreach and hence an important variable in measuring the operational success of the MFB. The study further revealed a difference of 0.0712 in the mean technical efficiency of MFBs located in commercial and agrarian communities, with the difference in favour of MFBs located in commercial communities. The location of MFB could influence the number of possible clients and hence determine the outreach potential of the MFB.

Table 5 revealed gross loan portfolio and external sources of funds as the determinants of MFBs' economic efficiency under the intermediation approach at $5 \%$ and $10 \%$ level of significance respectively. The quantum of loanable funds available for the MFB is an important determinant of the scale of its operations and hence profitability and efficiency. The significance of gross loan portfolio in the operational activities of MFBs is buttressed by the significance of the coefficient for external sources of funds as a determinant of the MFBs' 
economic efficiency. External sources of funds boost the loanable funds available for MFBs' operation and ultimately enhance their profitability. It provides MFBs' with a higher resource base to reach more clients and also reduce their cost of serving their client caseload. However, the study revealed that external sources of funds minimally hamper the technical efficiency of the MFBs. This could be due to the fact that cheap wholesale funds are not currently available to the MFBs, which ultimately affects the quantum of funds they can mobilize for their operations. Regulatory authorities should consider a window for wholesale lending for MFBs that will reduce their cost of funds and increase their access to loanable funds. This will dovetail into reduced interest rates for their clients, enhance MFBs' outreach and ultimately boost their efficiency and profitability.

The MFB's operational strategy (i.e., micro-credit only or micro-credit and other services) was expected to be a determinant of its outreach. A variety of microfinance products and services was expected to provide a broad range of options and present the MFB as a one-stop shop to both its active and potential customers. This was expected to create a diverse client base and hence stimulate better outreach. However, the non-significance of the variable could be due to the fact that most of the MFBs that claim to offer these other services have them only on their books as most of the services are not operationalized. Also the poor capacity of the MFB operators to develop these other product and services into profit units has limited their appearance as more of marketing gimmicks than microfinance services. Regulatory authorities should assist MFBs in developing model products and services along these product lines to further deepen service delivery by MFBs.

The age of the MFB was also expected to be significant as microfinance follows the learning curve concept of perfection through repeated practice. MFBs with longer years of experience were expected to have perfected their outreach strategy and have well-structured growth pattern than their counterparts who are new in the system. However, considering the fact that the MFBs operations were pooled over the 5 years of the study period, the learning experience could have been smoothened out over the 5 years as most of the MFBs would have stabilized their operations and adopt preferred practices in reaching their potential clients.

Quality of management staff was a variable that was also expected to influence the technical efficiency of the MFBs. Management staff with additional academic and professional qualifications were expected to add value to the operations of their banks and ultimately increase their efficiency. However, the targeted clients of microfinance are mostly the unbanked who are often illiterate or semi-literate. Hence secondary education with basic accounting and book keeping techniques might just be sufficient for the delivery of microfinance services. This raises the need for caution on the certification programme instituted for the top management of the MFBs as contained in the Revised Microfinance Policy, Regulatory and Supervisory Framework.

Table 4. Tobit regression result under the production approach

\begin{tabular}{|c|c|c|c|}
\hline \multicolumn{4}{|c|}{ Dependent variable: MFBs' pooled TE scores $(\mathrm{N}=86)$} \\
\hline Variables & Coefficients & t-ratio & Marginal Effect \\
\hline $\mathrm{C}$ & 0.520 & 2.266 & \\
\hline AGE & -0.0031 & -0.647 & -0.0031 \\
\hline LOC & $-0.0725^{*}$ & -1.864 & -0.0712 \\
\hline QOS & 0.0439 & 0.644 & 0.0431 \\
\hline $\mathrm{OP}$ & 0.0008 & 0.007 & 0.0008 \\
\hline AVC & $1.68 \mathrm{E}-05^{* * *}$ & 4.217 & $1.66 \mathrm{E}-05$ \\
\hline
\end{tabular}

Source: Field survey (2013).

** significant at 1 percent, * significant at 10 percent; AGE = Years of operation of MFB; AVC = Mean of individual MFBs' Average number of clients; OP = MFBs' operational strategy (dummy variable equals 1 for micro-credit and other services and 0 otherwise; LOC $=$ MFBs' location (dummy variable equals 1 for MFBs' located in agrarian communities and 0 otherwise; QOS = Quality of Management staff. 
Table 5. Tobit regression result under the intermediation approach

\begin{tabular}{|c|c|c|c|}
\hline \multicolumn{4}{|c|}{ Dependent variable : MFBs' pooled TE scores $(\mathrm{N}=86)$} \\
\hline Variables & Coefficients & t-ratio & Marginal Effect \\
\hline C & -0.0084 & -0.039 & - \\
\hline$A G E$ & 0.0059 & 1.305 & 0.0052 \\
\hline$L O C$ & 0.0035 & 0.096 & 0.0031 \\
\hline QOS & 0.0310 & 0.489 & 0.0275 \\
\hline$O P$ & -0.0034 & -0.030 & -0.0030 \\
\hline$G L P$ & $6.58 \mathrm{E}-10 * *$ & 1.975 & $5.84 \mathrm{E}-10$ \\
\hline$E S F$ & $-9.69 \mathrm{E}-10 *$ & -1.680 & $-8.60 \mathrm{E}-10$ \\
\hline
\end{tabular}

Source: Field survey (2013).

* significant at 10 percent, ${ }^{* *}$ significant at 5 percent; AGE $=$ Years of operation of MFB; GLP $=$ Mean of individual MFBs' Gross loan Portfolio; OP = MFBs' operational strategy (dummy variable equals 1 for micro-credit and other services and 0 otherwise; LOC $=$ MFBs' location (dummy variable equals 1 for MFBs' located in agrarian communities and 0 otherwise; QOS = Quality of Management staff; ESF = External Sources of Funds.

\section{Summary and Conclusion}

The aim of this study was to examine the technical and economic efficiency of MFBs in South-West Nigeria and also identify determinants of the differences in their efficiencies. MFBs were licensed to provide financial services to the economic active poor whose primary means of livelihood are concentrated along the agricultural value chain. Production and intermediation approaches were considered in this study to meet the double-edged microfinance objectives of outreach and financial stability.

The study revealed that the growth in outreach of the MFBs, in terms of their average number of clients per MFB grew between $10.58 \%$ and $22.08 \%$ over the study period. The MFBs mean number of active borrowers per MFB increased from 748 clients in 2006 to 1,464 clients in 2010, while their mean number of active savers per MFB rose from 1,821 clients in 2006 to 3,272 clients in 2010. This could be an indication of the MFBs' weak financial intermediation strategy as they have not been able to channel the savings mobilized into credit and other forms of loans for their clients.

The production approach examined the outreach objective of MFBs with the estimation of technical efficiency under the variable returns to scale measure, as all the MFBs were not expected to be operating at optimal level. The study reported a mean annual technical efficiency of 0.464 and only $30.23 \%$ of the sampled MFBs had technical efficiency score estimates of between 0.61 and 1.0. The study also reported that $78.37 \%$ of the MFBs were operating at increasing returns to scale, a good indication that the MFBs could get it right if they continue adopting best-practices. The observed trend in technical efficiency further supported the earlier positions on the MFBs' inconsistency but also underscores the need for MFBs to increase their outreach and explore the enormous opportunities offered by the huge potential client base.

The intermediation approach considered the MFB as a financial unit involved in financial intermediation for the objectives of profitability and financial sustainability. The study showed that MFBs were more allocatively efficient than they were technically with average allocative efficiency score of 0.288 compared with the average technical efficiency score of 0.167 . The mean economic efficiency score was 0.055 with an average of 2 MFBs on the economic efficiency frontier. This observed trend follows earlier submissions on the poor outreach level of the MFBs and highlights the need for MFBs to strive to balance both their outreach and financial stability objectives.

The production approach identified average number of clients and location of MFB as the determinants of efficiency though MFBs in commercial communities were more technically efficient than their counterparts in the agrarian communities. Average number of clients represents the level of outreach of the MFB and hence could influence the technical efficiency of the MFB. Location could determine the potential client base of the MFB and hence an indicator of the outreach potential of the MFB.

The intermediation approach identified gross loan portfolio and external sources of funds as the determinants of the economic efficiency of the MFB. MFBs are involved in financial intermediation and the quantum of loanable funds available to them could significantly determine their level of profitability. Adequate and cheap external sources of funds help to inject additional loanable funds into the operations of the MFB, which translates to increased outreach and reduced cost of serving their client caseload. The newly launched Micro, Small and Medium Enterprise Development Fund (MSMEDF) will go a long way to ease this challenge if it is properly 
administered with long-run microfinance objectives as its main thrust.

\section{Recommendation}

The focus of this research was on identifying the inherent potentials of MFBs as an instrument of genuine economic development through the empowerment of the economic active poor whose core economic activities are located along the agricultural value chains. Based on the findings of this research, the following recommendations were made:

1) The study showed that the microfinance sub-sector is presently inefficient and MFB operators should adopt best practices and increase their outreach towards attaining better efficiency levels.

2) The study revealed that the MFBs have higher allocative efficiency scores than technical efficiency scores. MFBs should step up their outreach through publicity and product diversification, and increase client mobilization as a meaningful client base is crucial to the realization of both outreach and financial stability objectives.

3) The Tobit estimation showed that using location as an efficiency shifter, the MFBs in the commercial communities were on the average more technically efficient than their counterparts in the agrarian communities. The regulatory authorities should consider extra incentives for MFBs in the agrarian areas to boost their outreach and overall technical efficiency. Rural financial literacy programmes and capacity building of MFB operators in the rural communities could catalyse activities in the rural microfinance sub-sector and accelerate the progress of the financial inclusion strategy.

\section{References}

Banerjee, A., Duflo, E., Glennerster, R., \& Kinnan, C. (2009). The miracle of microfinance? Evidence from a randomized evaluation. Retrieved from http://econ-www.mit.edu/files/4162

Ben Amor, T., \& Muller, C. (2010). Application of stochastic production frontier in the estimation of technical efficiency of irrigated agriculture in Tunisia. Agricultural Journal, 5(2), 50-56. http://dx.doi.org/10.3923/aj.2010.50.56

Berger, A., \& Humphrey, D. B. (1992). Mega mergers in banking and the use of cost efficiency as an antitrust defense. Antitrust Bulletin, 37, 541-600.

Brau, J. C., \& Woller, G. M. (2004). Microfinance: a comprehensive review of the existing literature. Journal of Entrepreneurial Finance and Business Ventures, 9, 1-26.

CBN (Central Bank of Nigeria). (2011). Microfinance policy, regulatory and supervisory framework for Nigeria. CBN, Abuja, Nigeria.

Chemin, M. (2008). The benefits and costs of microfinance: Evidence from Bangladesh. Journal of Development Studies, 44(4), 463-484. http://dx.doi.org/10.1080/00220380701846735

Christen, R. P., Rhyne, E., Vogel, R. C., \& McKean, C. (1995). Maximizing the outreach of microenterprise finance: An analysis of successful microfinance programs. Program and Operations Assessment Report No. 10. Washington, D.C.: U.S Agency for International Development.

Copestake, J., Dawson, P., Fanning, J. P., McKay, A., \& Wright, R. K. (2005). Monitoring the diversity of the poverty outreach and impact of microfinance: A comparison of methods using data from Peru. Development Policy Review, 23(6), 703-723. http://dx.doi.org/10.1111/j.1467-7679.2005.00309.x

Desrochers, M., \& Lamberte, M. (2003). Efficiency and expense preference behavior in Philippines' cooperative rural banks. Centre interuniversitairesur les risque, les politiques economiques et l'emploi (CIRPÉE.) Cahier de recherche/Working paper 03-21.

Dunford, C. (2006). Evidence of microfinance's contribution to achieving the millennium development goals. Freedom from Hunger. from http://microfinancegateway.org/files/35795_file_Evidence_on_MDGs_Dunford.pdf

Duvendack, M., \& Palmer, J. R. (2012). High noon for microfinance impact evaluations: Re-investigating the Evidence from Bangladesh. The Journal of Development Studies, 48(12), 1864-1880. http://dx.doi.org/10.1080/00220388.2011.646989

Farrell, M. J. (1957). The measurement of productive efficiency. Journal of the Royal Statistical Society, 120, $253-$ 281. http://dx.doi.org/10.2307/2343100

Farrington, T. (2000). Efficiency in microfinance institutes. Microbanking Bulletin, 20-23.

Ferrier, G. D., \& Lovell, C. A. K. (1990). Measuring cost efficiency in banking: Econometric and linear 
$\begin{array}{lllll}\text { programming } & \text { evidence. Journal of }\end{array}$ http://dx.doi.org/10.1016/0304-4076(90)90057-Z

Fried, H. O., Lovell, C. A. K., \& Schmidt, S. S. (2008). Efficiency and productivity. In H. O. Fried, C. A. K. Lovell, \& S. S. Schmidt (Eds.), The measurement of productive efficiency and productivity change (pp. 3-91). New York: Oxford University Press. Oxford Scholarship Online.

Gonzalez, V. C. (1986). Mercados financierosy desarrollo. Santo Domingo, R. D.: Centro de Estudios Monetariosy Bancarios.

Gonzalez, V. C. (1994). Regulación, competenciay eficiencia en la banca costarricense. In C. V. Gonzalez \& E. M. Camacho (Eds.), San José, Costa Rica: Proyecto Servicios Financieros (pp. 3-35). Ohio State: Ohio State University, Academia de Centroamérica.

Haq, M., Skully, M., \& Pathan, S. (2009). Efficiency of microfinance institutions: A data envelopment analysis. Journal of Economic Literature.

Hassan, M. K., \& Tufte, D. R. (2001). The X-efficiency of a group based lending institution: The case of Grameen Bank. World Development, 29, 1071-1082. http://dx.doi.org/10.1016/S0305-750X(01)00014-6

Hermes, M., \& Lensink, R. (2011). Microfinance: Its impact, outreach, and sustainability. World Development, 39(6), 875-881. http://dx.doi.org/10.1016/j.worlddev.2009.10.021

Honohan, P., \& King, M. (2009). Cause and effect of financial access: Cross-country evidence from the finscope surveys. World Bank mimeo.

Hulme, D., \& Mosley, P. (1996). Finance against poverty. London: Routledge.

Khandker, S. R. (2005). Microfinance and poverty: Evidence using panel data from Bangladesh. World Bank Economic Review, 19(2), 263-286. http://dx.doi.org/10.1093/wber/lhi008

Lafourcade, A., Isern, J., Mwangi, P., \& Brown, M. (2005). Overview of the outreach and financial performance of microfinance institutions on Africa. Retrieved from http://www.mixmarket.org

Martinez, G. A. (2008). Technical evidence of microfinance institutions: Evidence from Mexico. M. Sc. thesis, Ohio State University.

Menkhoff, L., \& Rungruxsirivorn, O. (2010). Do village funds improve access to finance? Evidence from Thailand. World Development, 39(1), 110-122. http://dx.doi.org/10.1016/j.worlddev.2010.09.002

Montgomery, H., \& Weiss, J. (2011). Can commercially-oriented microfinance help meet the millennium development goals? Evidence from Pakistan. World Development, 39(1), 87-109. http://dx.doi.10.1016/j.worlddev.2010.09.001

Noreen, U., Imran, R., Zaheer, A., \& Saif, M. I. (2011). Impact of microfinance on poverty: A case of Pakistan. World Applied Sciences Journal, 12(6), 877-883. Retrieved from http://idosi.org/wasj/wasj12(6)/21.pdf

Odell, K. (2010). Measuring the impact of microfinance: Taking another look. Washington, DC: Grameen Foundation. Retrieved from http://www.grameenfoundation.org/resource/measuring-impact-microfinance

Pitt, M. M., \& Khandker, S. R. (1998). The impact of group-based credit programs on poor households in Bangladesh: Does the gender of participants matter? Journal of Political Economy, 106(5), 958-996. http://dx.doi.org/10.1086/250037

Rhyne, E., \& Otero, M. (1994). The new world of microenterprise finance: Building healthy financial institutions for the poor. Kumarian Press Inc.

Roodman, D., \& Morduch, J. (2009). The impact of microcredit on the poor in Bangladesh: Revisiting the evidence. Working paper 174, Washington, DC: Center for Global Development.

Scully, N. (2004). Microcredit: No panacea for poor women. Washington, DC: Global Development Research Centre. Retrieved from http://www.gdrc.org/icm/wind/micro.html

Sherman, H. D., \& Gold, F. (1985). Bank branch operating efficiency. Evaluation with data envelopment analysis. Journal of Banking and Finance, 9, 297-315. http://dx.doi.org/10.1016/0378-4266(85)90025-1

Siebel, H. D. (2007). The role of microfinance in rural microenterprise development. Syngenta foundation for sustainable agriculture. WRO 1002.11.52. Retrieved from www.syngentafoundation.org

Simanowitz, S. (2002). Microfinance for the poorest: A review of issues and ideas for contribution of imp-Act. South Africa: Imp-Act Consortium. Retrieved from 
http://www.microfinancegateway.org/gm/document-1.9.24689/46.pdf

Van Rooyen, C., Stewart, R., \& De Wet, T. (2012). The impact of microfinance in Sub-Saharan Africa: A systematic review of the evidence. World Development, 40(11), $2249-2262$. http://dx.doi.org/10.1016/j.worlddev.2012.03.012

Zeller, M., \& Meyer, R. L. (2002). The triangle of microfinance: Financial sustainability, outreach and impact. Baltimore and London: The John Hopkins University Press. In conjunction with the International Food Policy Research Institute, Washington, DC.

\section{Copyrights}

Copyright for this article is retained by the author(s), with first publication rights granted to the journal.

This is an open-access article distributed under the terms and conditions of the Creative Commons Attribution license (http://creativecommons.org/licenses/by/3.0/). 